\title{
The Importance of Authentic Materials and their Integration in the Foreign Language Class
}

\author{
Msc. Sonila Piri \\ Tirana University, Faculty of Foreign Language, Italian Department \\ sonilap@yahoo.com \\ Dr. Aida Gjinali \\ Tirana University, Faculty of Foreign Language, Italian Department \\ aidagjinali@yahoo.it
}

\section{Doi:10.5901/ajis.2014.v3n6p27}

\section{Abstract}

In order to encourage foreign language teachers to use authentic materials during their classes, we have compiled some advantages that have been brought forth by some studies conducted on this topic. We believe that audiovisual and multimedia technologies are a very valuable source of authentic materials, which represent not just the language, but also the culture, traditions, behaviours and history of the country being studied. The teacher can use these materials, after he has done a careful selection and he has to integrate them by teaching them, so that he can use them in didactic activities according to the specific objectives. After the study done with the network, there have been selected some addresses where foreign language teachers can find proper updated authentic materials, attractive and motivating, but also didactic materials created with authentic materials from teachers and experts, which enable the closeness of the language to the varieties it represents.

Keywords: technology, authentic materials, students, teachers, objectives

\section{Why Should Foreign Language Teachers use Authentic Materials in their Class?}

The notion "authentic materials" has been used for the first time in glottodidactics by the middle of the 70s in the past century, and has later become the main focus of communicative approaches.

In the field of foreign language teaching, authentic materials are considered those texts compiled spontaneously by a person for one or more interlocutors in their native language. These texts should not be modified, but they need to represent the proper linguistic pattern.

Also, we can consider as authentic those texts which, for didactic purposes, can be facilitated from excessive information, such as: dates, names, etc, without losing their original physiognomy.

Those texts, elaborated from the foreign language teacher for didactic purposes, which a native speaker can easily consider as of his own language, can be considered as texts "built" to differentiate from proper authentic texts.( Comodi A., 1995, pg. 9)

Some other researchers support the thesis that a material can be considered as authentic in relation to its cultural content, that is the cultural context it conducts.

The researches of this field claim that the presentation of authentic materials in foreign languages' classes represents an original exhibition of the culture the language we are learning belongs to, in a specified moment and context by demonstrating to students a pattern of understanding situations and behaviours of native speakers. (Katerinov K. Et alii, 1991)

The foreign language teacher who uses authentic materials in his classes infects his students with curiosity towards possible cultural differentiations. Even similar cultural elements between the two compared cultures brings pleasure in the ability that the student expresses in the comparison of the cultures, by making him feel confident by knowing how to behave in similar situations. (Comodi A., 1995, pg 9).

Scholar Balboni(Balboni P., E., 1994) affirms that comparison of the foreign language via intercultural approaches and confrontations promotes a kind of familiarity to a social-cultural pattern, where linguistic presentation is now considered as a component and a very necessary one in case the student wants to learn more regarding that particular social-cultural pattern.

Getting familiar with the language's history, civilization and traditions through the usage of authentic texts, makes it possible for the student to know and respect the other culture even for the alternation compared to his own culture.

Moreover, getting to know new worlds enables the student conduct an analysis of cultural relativity (Balboni, P.E. 
1999 Pg. 24) and enrich his knowledge on the culture and the foreign language he is learning.

Studies conducted in this field show that when the student discovers the language, traditions, behaviours and history of the foreign country, he tries to find similarities and differences in his own culture and language, thus encouraging him to reflect on the social-cultural reality he was born and raised in.

We should take into consideration another aspect, important as well, that using authentic materials as "witnesses" of the foreign language culture, civilization and behaviours, make it easier for the student to discover the foreign language and culture, but also to know oneself. . (Comodi A., 1995, pg 10).

We believe that authentic materials are essential in those cases when the texts in use are a little bit old, but also in those cases when they do not contain enough information on the language and the culture mainly.

Even the Common European Framework of Language Reference (CEFL, 2001, Chapter 4) deals with aspects of using visual and spoken inputs of different media and programs in the teaching of foreign languages. As a consequence, it results that it is very necessary that these materials are frequently used in the language didactics, for they represent the language in its original context. For example, a movie helps students understand the language through the help of all prelinguistics elements (talking speed, hesitations, different tones) and extra linguistic (body movements, gestures, mimics, clothes, etc. ).

Authentic materials should be integrated into those classes where the foreign county is far away and mainly when it is not possible for the students to visit it and stay there for a short period.

Specifically, the use of vocal authentic materials through specific activities makes possible the development of phonological, grammatical, lexical, semantic, morphological, syntax and pragmatic competences by transmitting to the student the expectancy grammar.

Integration through specific activities of written authentic materials activates expectancy grammar and deepens lexical, semantic, grammatical, syntax and pragmatic competences.

With regards to the audiovisual materials, according to Begley, (Begley S., 1999), 83\% of the information that enters our brain follows the visual channel and only $11 \%$ follows the audio one. Therefore, if audiovisual materials are combined with a kind of interaction, they would be very efficient for memorizing and learning a foreign language.

On the other side, the scholar Cardona (Cardona M., 2007) claims that "the use of audiovisual materials can help developing lexical competences". According to him, when a student is presented with an audiovisual material, he can observe the linguistic act within the communication context, a moment that helps the proper development of lexical competence, even though the audiovisual sequence contains different linguistic and extra linguistic aspects that form complicated aspects of communicative interaction." Also, according to Cardona, "the audiovisual input favours the transition of words from a receptive lexicon to a productive one by increasing the student's communicative abilities" (Cardona M., 2007).

If we compare vocal and written texts, the latter are more enriched with movements, gestures, objects and body placement, therefore, they have more extra linguistic elements.

Figurative texts make it possible for the student to build hypothesis and predict the purposes of the images, etc. Also, such a text is always full of cultural elements of the foreign language, and also with additional extra linguistic elements.

\section{Which are the Authentic Materials that can Derive from Audiovisual and Multimedia Technology and how can they be Integrated into the Foreign Language Subject}

If we take into consideration a more enriched reality with the multimedia context offered from informatics, the audiovisual devices actually represent just a small part of the available media sources. Still, a large number of books on foreign language teaching and the sources it takes into consideration guide us to infinite materials and provided inputs from television and cinematography which are easily exploitable. Therefore, both television and cinematography provide quite a lot of information on the linguistic and cultural context of a definite society. It is important that the audiovisual material that the teacher will use in his class belong to a learning unit, which has to be linked to other segments, whether it is a module or a wider didactic unit or a lecture.

It is without any doubt true that today internet gathers many of the possibilities offered from different media, and, above all, enables finding and using infinity of authentic materials, very valuable from the linguistic and cultural point of view, which can be stored in a computer, can be printed and used in the language class.

The materials and tools offered from internet belong a wider topic, but we will suggest for a more practical usage from language teachers: 
- Samples of the authentic language

- $\quad$ Actual updated information (the most recent information)

- Interactive exercises

- Programs on language learning

- Programs on the development of coherent exercises

- Texts or other multimedia materials and internet web pages that can be used online or than can be downloaded

Of course, if they are used in teaching activities, the web materials need to be programmed, just like any other teaching activity. First of all, the language teacher should explore possible addresses and analyze them in details, in order to evaluate their compatibility with the class topics, the linguistic level of the class they will be used in, and other technical aspects, such as, internet connection, or the computers' capability of downloading quickly. Teachers should evaluate even the cases when there is no internet connection, and because of this they should download these pages beforehand and use them in the offline mode.

Moreover, the movie materials that teachers choose to use in the class are not didactic materials and can become demotivational materials when they are not in the same linguistic level of the students, that's why it is the teacher's duty to select some parts on which he can build activities. It is advisable that the movie parts are popular amongst the students, not just according to the teacher's preference.

As it was mentioned above, the selected audiovisual or multimedia materials should be elborated and integrated in appropriate learning units that are attached to the objectives of teaching the text, as it has been predicted in the curriculum or to be integrated on teacher's initiative as additional materials on some specific linguistic, cultural, communicative, extra linguistic, etc, objectives, that cannot be found in the book, but which the teacher considers as valuable to be treated and learned from students, or to be used for enforcing different aspects or competences which students are lacking.

\section{Online Authentic Materials for the Italian Language Class}

Thanks to a research we did online, we will present a few web pages, where Italian language teachers can find authentic materials, and also, didactic materials that have been made ready and have been elaborated from Italian language teachers and professionals.

- http://venus.unive.it/italslab/modules.php?op=modload\&name=ezcms\&file=index\&menu=94\&page_id=385

is one of the addresses we have selected, for it offers multiple didactic materials, divided according to different topics. We believe that the topic "Materiali për la Didattica" (Didactic materials) would be very useful to Italian language teachers, because there they can find didactic materials and units prepared from Italian language professors, professionals and teachers. These activities have been built on different didactic materials, such as songs, videos, etc, that have been carefully chosen, adapted to different levels of Italian language knowledge. Under this topic, there are eight teaching patterns that include different aspects of the Italian grammar, culture and literature.

- http://www.learnitalianvideos.com/

In the above selected address, one can find many video clips with different exercises that help improve the understanding capability. We will suggest the topic "Impariamo l'italiano" (Let's learn Italian), which is very interesting and contains many lexical exercises for beginners and intermediate levels of Italian language, built as games on different didactic levels and techniques. We believe that these activities can be used in the Italian language class, because they are motivating, due to selected techniques, and also for their colourful and easily verified format.

- http://www.scudit.net/mdindice.htm

We have selected the above address, because there can be found many didactic materials, which are updated every 15 days, and cover different levels, from the beginning to the advanced. These materials are different, such as exercises on the linguistic reflection, text understanding, etc. Beside the use of the computer during the Italian language class, the materials can be downloaded, printed and used in class. There are approximately 100 didactic materials, which make it one of the most enriched web pages. Authentic materials, such as lyrics or songs, interviews, etc., have been carefully selected, are updated and divided according to the linguistic levels. Even the exercises that accompany these materials have been built on different techniques, which make them possible to be used and adapted to students according to their individual capacity on the linguistic learning.

- www.centrocome.it

This address contains many materials on the Italian language teaching, communicating and studying. Materials 
belong to different fields, such as history, culture, civilization, etc. They have been prepared into a simple language, specifically for foreign students, and because of this they can be presented and used in the Italian language classes.

- http://www.teche.rai.it/

This is the official webpage of the RAI (Italian Radio and Television) Directory of Archive. Here, one can find many multimedia authentic materials which can be processed and used in classes. Above all, in this address one can find many history and television materials.

- www.ilnarratore.com

In this webpage, one can find many .mp3 materials of narrative nature and history listening. Materials vary from Italian classic and modern literature, poetry, child stories, society books, biography, etc. The documents can be downloaded and used for didactic purposes. We believe that they can be appropriate as authentic audio materials, because they have a proper didactic duration (from1-5 minutes) to implement them within the didactic units.

- www.lportaledeibambini.net

Italian language teachers of elementary school can find here many authentic materials that can be used in classes as reading materials, but they can be elaborated from the teacher himself. Also, there is information on Italy, which can be used to extend the knowledge on this country's culture, history, geography, etc.

- www.stroccofillo.it

The above address is rich on narrative materials, such as fairy tales, poetry, songs, riddles, lullabies, etc. Materials belong to many famous authors, such as Gianni Rodari, but also many materials prepared from young people and children. Also, in this address one can find materials on other topics, such as games, riddles, crosswords, labyrinths, recipes, notifications, etc. Authentic materials can be selected from Italian language teachers to be later used in classes or students can be invited to perform online activities, such as group work, or at home, in order to extend their contact with the Italian language for a more long-term learning.

Even the daily press is considered rich in authentic materials which can be used from Italian language teachers in their classes. Through newspapers it is possible to know their linguistic and stylistic differences to the standard Italian language, in order to define text typologies which are essential in teaching the Italian language as a foreign one.

The daily press does not contain only chronicles, but also cultural, sports, economic news, additional sections dedicated to the actual news, which can be used as authentic materials, in order to get the students familiar with the reality and culture of the foreign language they are learning. In the webpage http://www.quotidiani.net/ one can find the addresses of the main Italian newspapers.

\section{Conclusions}

In order to create a more natural environment with the language they are teaching, teachers should use more authentic materials, because they enable knowing it in its social-cultural, regional and individual varieties, within the proper authentic moments of communication.

So, through the use of authentic materials, students will have the possibility to feel part of the reality and culture of the language they are learning. Teachers should offer updated authentic materials, which are attractive, interesting, motivating, and functional and which can adapt to the linguistic needs and students' interest, in order to guarantee an effective learning, which enables the interaction and deepens the linguistic knowledge through specific activities.

On the other side, authentic materials offer the possibility to students to reflect on the context, on the environment the foreign language is expressed and developed, by having the possibility to detect quick changes that it can represent.

\section{Bibliography}

Balboni, P.E. (1994) Didattica dell'Italiano a stranieri, Bonacci, Roma

Balboni, P.E. (1999) Dizionario di Glottodidattica, Guerra Edizioni, Perugia, page 24

Begley, S. (1994) Teaching Mind to fly with Discs and Mice, Newsweek, 31 may

Cardona, M. (2007) II testo udiovisivo e lo sviluppo della competenza lessicale, in M. Cardona, Vedere per capire e parlare. II testo audiovisivo nella didattica delle lingue, (a cura di), UTET Università, Torino

Comodi, A. (1995) Materiali autentici: selezione e uso nella didattica dell'italiano come lingua straniera, Guerra, Perugia, page 9

Favaro, L. dhe Sandrini, I. Materiali e applicativi web per la didattica delle lingue, in F. Caon, G. Serragiotto, (2012), Tecnologie e didattica delle lingue, Utet università, Torino

Guariento, W. Morley, J. (2001) Text and authenticity in EFL classroom ne ELT Journal 4

Katerinov, K. et alii (1991) L'insegnamento della cultura e civiltà nei corsi di italiano come L2, CILA, 5, Guerra, Perugia, page 5 